\title{
Maternal Microchimerism in Juvenile Tonsils and Adenoids
}

\author{
ANNA MARIA JONSSON, NIKOS PAPADOGIANNAKIS, ANNA GRANATH, JENNY HAGGSTROM, MARIE SCHAFFER, \\ MEHMET UZUNEL, AND MAGNUS WESTGREN
}

\begin{abstract}
Department of Obstetrics and Gynecology [A.M.J., M.W.]; Department of Laboratory Medicine [N.P., M.S., M.U.]; Department of Ear, Nose, Throat, and Cochlear [A.G., J.H.]; Karolinska Institute and Karolinska University Hospital, Huddinge, 14186 Stockholm, Sweden
\end{abstract}

\begin{abstract}
During pregnancy small amounts of cells pass between the mother and the fetus, and this transfer may give rise to a chimeric state that persist for years in both individuals. Both fetal and maternal microchimerism (MMc) have been associated with different autoimmune disorders. Information about MMc in tissues of healthy individuals is sparse but is important when looking for maternal cells within affected tissues of certain diseases. The aim of this study was to investigate the occurrence of maternal cells in tonsils and adenoids of 20 healthy children between the ages of 2 and 15 years. All the children underwent surgery because of recurrent tonsillitis or respiratory obstruction. MMc was detected using an RT-PCR assay based on differences in gene polymorphisms between mother and child. We found maternal cells in the tonsils and/or adenoids in four of 20 children. This frequency is less than the frequency of maternal cells found in the peripheral blood of healthy adults but in agreement with the previously reported frequency of maternal chimerism in control tissues. (Pediatr Res 68: 199-204, 2010)
\end{abstract}

$\mathrm{B}^{\mathrm{i}}$ idirectional passage of maternal and fetal cells across the placenta can give rise to a chimeric state that persists for years in both the mother and her offspring $(1,2)$. The function and the significance of these semiallogenic cells are not known. Although the consequences of fetal microchimerism (a small amount of fetal cells in the mother) are not unknown, fetal cells have been speculated to be involved in triggering autoimmune disorders (3-7) or to act as a rejuvenating source involved in tissue repair processes $(8,9)$. Other reports point to fetal chimeric cells as "innocent bystanders" in inflammatory or healing processes (10).

The passage of a small amount of maternal cells to the offspring during pregnancy, maternal microchimerism (MMc), has been studied to a lesser extent than fetal microchimerism. Cells of maternal origin have been detected at various concentrations in fetal blood from week 13 (11) and in up to $100 \%$ in cord blood samples depending on the method used for detection of maternal cells (12-14).

We recently reported the detection of maternal immunocompetent cells in 11-s trimester fetuses (15) that were aborted due to malformations and/or trisomy 21 or for social reasons. Maternal cells were found in seven of the 11 fetuses, and these cells expressed surface markers for $\mathrm{T}$ - and $\mathrm{B}$ -

Received November 9, 2009; accepted May 20, 2010.

Correspondence: Anna Maria Jonsson, M.D., Department of Obstetrics and Gynecology K57, Karolinska University Hospital, Huddinge, 14186 Stockholm, Sweden; e-mail: anna.jonsson@karolinska.se

Supported in part by grants from the Swedish Medical Research Council and Stockholm's County. lymphocytes, leukocytes, and hematopoietic progenitor cells. The maternal cells were present in all organs investigated and were found in both normal fetuses and in those with malformations and/or trisomy 21.

Furthermore, Stevens et al. (16) recently showed that maternal cells were present in various tissue types in seven male infants. They also showed that the maternal cells were differentiated into specific organ cell types. Maloney et al. (2) showed that cells of maternal origin were present in the blood of healthy individuals through middle-age.

As with fetal microchimerism, maternal cells in the offspring have been associated with different autoimmune diseases especially conditions that arise in children (17-25). Because the fate of those semiallogenic maternal cells is largely unknown, particularly in tissues of healthy individuals, we sought to investigate whether maternal cells were present in lymphoid tissues of children during infancy in an attempt to elucidate an eventual role of MMc in immune development. In previous studies, we demonstrated the occurrence of mature maternal $\mathrm{T}$ and $\mathrm{B}$ cells as well as hematopoietic progenitors in various fetal tissues. In this study, we investigated MMc in tonsil and adenoid tissues, which are inherently rich in lymphoid cells and may even represent a potential site of postnatal lymphopoiesis (26).

\section{METHODS}

Patients. Tissue samples from the tonsils and/or adenoids of 20 children undergoing tonsillectomy and/or adenoidectomy were collected prospectively. From the literature and our previous work, and we assumed a $30 \%$ MMc prevalence in various tissues. Thus, we speculated that 20 cases should provide a sample size to test for the presence of maternal cells in tonsil and adenoid tissues of the offspring.

The indications for surgery were respiratory obstruction (snoring) and/or recurrent tonsillitis (Table 1). A questionnaire about the health conditions of both mother and child was given to the mother of the child. Questions included the length of breast-feeding time, the obstetric history of the mother, whether the mother or child had ever received a blood transfusion, and whether the mother or child was a twin. The characteristics of the children and their mothers are shown in Table 1 . None of the children or mothers was a twin or had ever received a blood transfusion, and all the participants were healthy except one mother with hypothyreosis and one with fibromyalgia. The obstetric history of the children was normal in all except in one case where the child was delivered in gestational week 33 because of abruption of the placenta (case 17).

Tissue collection. Peripheral blood was collected from the mothers and the children. In the children, both tonsils and adenoids were removed by curettage under general anesthesia and sent to the Pathology Department immediately after the operation for dissection and further analysis.

Abbreviations: MMc, maternal microchimerism 
Table 1. Characteristics of children and mothers

\begin{tabular}{|c|c|c|c|c|c|c|c|}
\hline Case & $\begin{array}{l}\text { Child's } \\
\text { age }\end{array}$ & Sex & $\begin{array}{l}\text { Maternal } \\
\text { age }\end{array}$ & $\begin{array}{l}\text { Obstetric } \\
\text { history* }\end{array}$ & $\begin{array}{c}\text { Allergy } \\
\text { (children) }\end{array}$ & Reason for surgery & $\begin{array}{c}\text { Breastfeeding } \\
\text { (mo) }\end{array}$ \\
\hline 1 & 2 & $\mathrm{~F}$ & 27 & $1 / 0 / 0$ & Asthma & Respiratory obstruction & 1 \\
\hline 2 & 2 & M & 37 & $1 / 1 / 0$ & Asthma & Respiratory obstruction & 6 \\
\hline 3 & 2 & M & 41 & $1 / 0 / 0$ & None & Respiratory obstruction, recurrent tonsillitis & 2 \\
\hline 4 & 3 & $\mathrm{~F}$ & 32 & $1 / 0 / 1$ & None & Respiratory obstruction, recurrent tonsillitis & 12 \\
\hline 5 & 3 & M & 43 & $1 / 0 / 0$ & None & Respiratory obstruction, recurrent tonsillitis & 7 \\
\hline 6 & 3 & M & 28 & $1 / 0 / 0$ & None & Respiratory obstruction, recurrent tonsillitis & 24 \\
\hline 7 & 3 & $\mathrm{~F}$ & 32 & $1 / 0 / 0$ & Asthma & Respiratory obstruction, recurrent tonsillitis & 12 \\
\hline 8 & 4 & M & 35 & $1 / 0 / 0$ & None & Respiratory obstruction, recurrent tonsillitis & 18 \\
\hline 9 & 4 & M & 31 & $1 / 0 / 2$ & None & Respiratory obstruction & 6 \\
\hline 10 & 5 & $\mathrm{~F}$ & 34 & $1 / 0 / 0$ & Nut & Respiratory obstruction & 12 \\
\hline 11 & 6 & M & 33 & $1 / 0 / 0$ & None & Recurrent tonsillitis & 6 \\
\hline 12 & 6 & M & 45 & $1 / 0 / 2$ & Asthma & Respiratory obstruction & 3 \\
\hline 13 & 6 & M & 39 & $1 / 0 / 0$ & None & Recurrent tonsillitis & 6 \\
\hline 14 & 6 & $\mathrm{~F}$ & 26 & $1 / 0 / 0$ & None & Recurrent tonsillitis & 2 \\
\hline 15 & 6 & M & 30 & $1 / 0 / 0$ & None & Recurrent tonsillitis & 0 \\
\hline 16 & 6 & M & 24 & $1 / 0 / 0$ & None & Respiratory obstruction, recurrent tonsillitis & 24 \\
\hline 17 & 7 & M & 37 & $3 / 0 / 0$ & None & Respiratory obstruction & 0 \\
\hline 18 & 8 & M & 36 & $1 / 1 / 0$ & None & Respiratory obstruction & 24 \\
\hline 19 & 8 & M & 34 & $1 / 0 / 0$ & None & Respiratory obstruction, recurrent tonsillitis & 6 \\
\hline 20 & 15 & $\mathrm{~F}$ & 56 & $1 / 1 / 0$ & None & Respiratory obstruction & 4 \\
\hline
\end{tabular}

* Full-term pregnancies/spontaneous abortion/termination of pregnancy.

The tissues were washed with sterile saline and dissected under sterile conditions. Each tonsil was divided into two halves. From each half, a piece of tissue measuring approximately $5 \times 5 \times 5 \mathrm{~mm}$ was collected for PCR analysis. Thus, a total of four fractions from each tonsil pair were included in the analysis (denoted T1 to T4). These fractions were harvested from the central area of the tonsil to avoid contamination by epithelial cells and possible inflammatory exudates on the surface of the crypts. The adenoid was similarly divided into two halves and a small (central) piece of tissue from each half was taken for PCR analysis. No histopathological examination of the tissues was performed. This study was approved by the Ethics Committee at Karolinska University Hospital (Dnr 2008/3:3). Institutional Review Board consent was obtained from all patients.

Quantitative $\boldsymbol{R} \boldsymbol{T}-\boldsymbol{P C R}$. DNA from blood, tonsil, and adenoid samples was extracted using Qiagen Mini Kit (Qiagen, Hilden, Germany). The concentration of DNA in the tissues was initially diluted to $100 \mathrm{ng} / \mu \mathrm{l}$, to yield a total amount of $500 \mathrm{ng}$ in each PCR reaction.

The primers and probes used for chimerism analysis were adapted from others $(27,28)$. In short, biallelic genetic systems were used to screen DNA samples. For each biallelic system, one of the primers was from the polymorphic region to specifically amplify each allele, whereas the second primer and the probe were common to both alleles. An allele was considered informative when it was positive for maternal DNA and negative for the child's DNA. Detection and quantification were performed with an ABI 7000 Sequence Detection System (Applied Biosystems, Foster City, CA) using TaqMan technology. The PCR parameters were as follows: $2 \mathrm{~min}$ at $50^{\circ} \mathrm{C}, 10$ min at $95^{\circ} \mathrm{C}$, followed by 40 cycles of $15 \mathrm{~s}$ at $95^{\circ} \mathrm{C}$ and $1 \mathrm{~min}$ at $60^{\circ} \mathrm{C}$. RQ-PCR reactions were performed in a total volume of $25 \mu \mathrm{L}$ containing $1 \times$ TaqMan Universal PCR Master Mix (Applied Biosystems, containing dNTPs with dUTP, $\mathrm{MgCl}_{2}$, AmpliTaq Gold DNA Polymerase, AmpErase UNG, Passive Reference), $5 \mu \mathrm{L}$ of DNA sample, $300 \mathrm{nM}$ of each primer, and 200 nM probe. The amount of amplifiable DNA in each sample was assessed by parallel amplification of the reference gene glyceraldehyde phosphate dehydrogenase (GAPDH). All samples were run in duplicate and both maternal and child DNA samples were included in each run. For a positive result, both reactions were required to yield amplification signals before cycle 40 . The negative controls included water and a low concentration (10 ng) blood-DNA sample from the corresponding child. Relative quantification of recipient DNA was calculated according to the $\Delta \Delta \mathrm{Ct}$ method (Applied Biosystems, user bulletin 2) using GAPDH as a reference gene and the maternal DNA sample as a calibrator. The formula used was $2^{-(\Delta \mathrm{CtU}-\Delta \mathrm{CtC})}$, where $\Delta \mathrm{Ct}=\mathrm{Ct}$ target gene $-\mathrm{Ct}$ reference gene. $\mathrm{U}$ was the unknown sample and $\mathrm{C}$ was the calibrator sample.

The specificity and sensitivity of the RQ-PCR method was determined for all markers included in this study using artificial DNA mixtures and varying DNA amounts. The PCR assay was validated by mixing DNA from one individual (positive for the three markers) in different concentration in a second individual (negative for the markers). The total amount of DNA was
$500 \mathrm{ng}$, which was demonstrated by a stable $\mathrm{Ct}$ value for GAPDH (data not shown). We detected no false positive results using $500 \mathrm{ng}$ DNA and 40 cycles of PCR amplification.

HLA determination. HLA-A, -B and -DRB1 polymorphisms were determined using standard PCR-based methods (LabType, One Lambda, Inc, CA) including sequence-specific oligonucleotide probes (PCR-SSOP) using xMAP technology (Luminex System, Luminex Corporation, Austin, TX).

\section{RESULTS}

Maternal cells were identified in four of 20 children (Table 2). The children that were positive for MMc in the tonsils and/or adenoids were two boys (cases 9 and 15) and two girls (cases 10 and 14) between 4 and 6 y of age. Cases 9 and 14 were positive in all tissue fractions as well as in the blood tested. Case 10 was positive for maternal cells in all fractions tested except in one of the tonsil fractions (T4) and in the two fractions of the adenoid. Case 15 was positive in only one of the four fractions of the tonsils and in blood. All cases positive for MMc in blood were also found positive in tonsil or adenoid tissue, in approximately similar rates. Detailed RT-PCR data for samples with MMc are shown in Table 3. No apparent correlation between the presence of maternal cells in the tonsils and/or adenoids and the various combinations of mother/child HLA classes was found (data not presented).

\section{DISCUSSION}

This study confirms previous reports indicating that MMc is a rather common phenomenon. Most studies have evaluated the incidence of MMc in patients affected by different diseases, although limited information has been reported regarding $\mathrm{MMc}$ in healthy individuals, especially in tissues. In second trimester, fetuses from socially motivated terminations, we demonstrated MMc in various organs in about $50 \%$ of the cases from the 13th week of gestation (15). Recently, Mold et al. (29) reported even higher MMc rates in fetal lymph nodes acquired from second trimester abortions. Up to 
Table 2. Detection of MMc in tonsils and adenoids

\begin{tabular}{|c|c|c|c|c|c|c|c|c|}
\hline Case & Sex & Blood & $\mathrm{T} 1$ & $\mathrm{~T} 2$ & T3 & $\mathrm{T} 4$ & A1 & A2 \\
\hline 1 & $\mathrm{~F}$ & $\mathrm{Neg}$ & $\mathrm{Neg}$ & $\mathrm{Neg}$ & $\mathrm{Neg}$ & $\mathrm{Neg}$ & NT & NT \\
\hline 2 & M & $\mathrm{Neg}$ & NT & NT & NT & NT & Neg & $\mathrm{Neg}$ \\
\hline 3 & M & $\mathrm{Neg}$ & $\mathrm{Neg}$ & $\mathrm{Neg}$ & $\mathrm{Neg}$ & $\mathrm{Neg}$ & Neg & $\mathrm{Neg}$ \\
\hline 4 & $\mathrm{~F}$ & $\mathrm{Neg}$ & $\mathrm{Neg}$ & $\mathrm{Neg}$ & $\mathrm{Neg}$ & $\mathrm{Neg}$ & NT & NT \\
\hline 5 & M & $\mathrm{Neg}$ & $\mathrm{Neg}$ & $\mathrm{Neg}$ & $\mathrm{Neg}$ & $\mathrm{Neg}$ & $\mathrm{Neg}$ & $\mathrm{Neg}$ \\
\hline 6 & M & Neg & Neg & $\mathrm{Neg}$ & $\mathrm{Neg}$ & Neg & Neg & Neg \\
\hline 7 & $\mathrm{~F}$ & $\mathrm{Neg}$ & $\mathrm{Neg}$ & $\mathrm{Neg}$ & $\mathrm{Neg}$ & $\mathrm{Neg}$ & $\mathrm{Neg}$ & $\mathrm{Neg}$ \\
\hline 8 & M & Neg & Neg & $\mathrm{Neg}$ & $\mathrm{Neg}$ & $\mathrm{Neg}$ & Neg & Neg \\
\hline 9 & M & $1 \times 10^{-3 *}$ & NT & NT & NT & $\mathrm{NT}$ & $5.3 \times 10^{-3}$ & $5.4 \times 10^{-3}$ \\
\hline 10 & $\mathrm{~F}$ & $3.4 \times 10^{-3}$ & $3.7 \times 10^{-3}$ & $7.1 \times 10^{-3}$ & $2.1 \times 10^{-3}$ & Neg & Neg & Neg \\
\hline 11 & M & Neg & Neg & Neg & Neg & $\mathrm{Neg}$ & $\mathrm{NT}$ & NT \\
\hline 12 & M & $\mathrm{Neg}$ & NT & NT & NT & NT & $\mathrm{Neg}$ & $\mathrm{Neg}$ \\
\hline 13 & M & Neg & Neg & Neg & $\mathrm{Neg}$ & Neg & NT & NT \\
\hline 14 & $\mathrm{~F}$ & $7 \times 10^{-3}$ & $2 \times 10^{-2}$ & $2 \times 10^{-2}$ & $2 \times 10^{-2}$ & $3 \times 10^{-3}$ & NT & NT \\
\hline 15 & M & $2.8 \times 10^{-3}$ & Neg & Neg & $7.5 \times 10^{-4}$ & Neg & NT & NT \\
\hline 16 & M & Neg & Neg & Neg & Neg & Neg & Neg & Neg \\
\hline 17 & M & $\mathrm{Neg}$ & Neg & $\mathrm{Neg}$ & $\mathrm{Neg}$ & Neg & NT & NT \\
\hline 18 & M & $\mathrm{Neg}$ & $\mathrm{Neg}$ & $\mathrm{Neg}$ & $\mathrm{Neg}$ & $\mathrm{Neg}$ & $\mathrm{Neg}$ & $\mathrm{Neg}$ \\
\hline 19 & M & Neg & Neg & $\mathrm{Neg}$ & $\mathrm{Neg}$ & $\mathrm{Neg}$ & NT & NT \\
\hline 20 & $\mathrm{~F}$ & $\mathrm{Neg}$ & NT & NT & NT & NT & Neg & Neg \\
\hline
\end{tabular}

* Percentage of maternal cells.

NT, not tested; neg, negative.

Table 3. RT-PCR data on samples with $M M c$

\begin{tabular}{clccc}
\hline Case & Sample & $\begin{array}{c}\text { Target } \\
\text { gene }(\mathrm{Ct})\end{array}$ & $\begin{array}{c}\text { GAPDH } \\
(\mathrm{Ct})\end{array}$ & $\begin{array}{c}\text { Ratio } \\
\text { (after calibration) }\end{array}$ \\
\hline 9 & Blood & 39.1 & 21.7 & $1.10 \mathrm{E}-05$ \\
9 & A1 & 37.9 & 22.8 & $5.30 \mathrm{E}-05$ \\
9 & A2 & 37.1 & 22 & $5.40 \mathrm{E}-05$ \\
10 & Blood & 37.1 & 21.9 & $3.40 \mathrm{E}-05$ \\
10 & T1 & 35 & 19.9 & $3.70 \mathrm{E}-05$ \\
10 & T2 & 34.4 & 20.3 & $7.10 \mathrm{E}-05$ \\
10 & T3 & 36.7 & 20.8 & $2.10 \mathrm{E}-05$ \\
14 & Blood & 38.8 & 23.3 & $7.00 \mathrm{E}-05$ \\
14 & T1 & 35.3 & 21.5 & $2.00 \mathrm{E}-04$ \\
14 & T2 & 35.5 & 21.7 & $2.00 \mathrm{E}-04$ \\
14 & T3 & 36.4 & 22.6 & $2.00 \mathrm{E}-04$ \\
14 & T4 & 38.2 & 21.5 & $3.00 \mathrm{E}-05$ \\
15 & Blood & 38.3 & 21.8 & $2.80 \mathrm{E}-05$ \\
15 & T3 & 38.5 & 21.2 & $7.50 \mathrm{E}-06$ \\
\hline
\end{tabular}

$\mathrm{Ct}$, threshold cycle. $\mathrm{Ct}$ values show the mean value of duplicates.

Ratio: the formula used was $2^{-(\Delta \mathrm{CtU}-\Delta \mathrm{CtC})}$, where $\Delta \mathrm{Ct}=\mathrm{Ct}$ target gene $\mathrm{Ct}$ reference gene (GAPDH).

$\mathrm{U}$ is the unknown sample and $\mathrm{C}$ is the calibrator sample (mother).

$100 \%$ of all children at birth, harbors maternal cells in cord blood (12-14), and the estimated frequency of maternal cells varies between 0.02 and $5 \%(9,11,12)$. Data on MMc after birth are primarily based on blood samples. MMc can persist to middle age, and depending on the method used for detection, MMc rates range from 20 to $39 \%$ in different cell populations in peripheral blood (30). Thus, MMc seems to be frequent and persists for many years.

Information on the amount and distribution of maternal chimeric cells in organs and tissues of healthy individuals may be crucial in understanding the eventual physiologic role of these cells; however, very few studies have addressed this issue. The results of these reports are summarized in Table 4. In studies on tissues from abortions, biopsies, and autopsy material, MMc have been demonstrated in a wide range of tissues such as skin, heart, liver, spleen, thymus, thyroid, and pancreas (15-25,29,30,31), and no particular organ has an apparent predilection for MMc. These reports vary greatly with regard to the frequency of $\mathrm{MMc}$ and cite frequencies from 0 to $100 \%$, although several limitations impacted the validity of the published results. In many cases, the patient material was limited in size, and the methods for detection were very disparate. Moreover, most of the controls used in the studies were patients affected with severe disease in the specific organ studied (i.e., skin, muscle, liver, etc) rather than healthy individuals.

This study is the first report on MMc in tonsil and adenoid tissues. Our investigation of these tissues was prompted, in part, by the fact that we could study maternal cells in lymphoid organs that are readily available in tissues of relatively healthy children. The tonsil and adenoid tissues develop after birth and constitute a first line of defense against microbial invasion of the upper aero-digestive system. Both B- and T-cell-related immunologic processes are initiated in different specialized compartments of the palatine tonsils $(32,33)$. Also, the adenoid is an active immunologic site in the nasopharyngeal region that harbors cells from both the innate and adaptive immune systems $(34,35)$.

Here, we analyzed fresh tissue, targeting non-shared maternal polymorphic regions in the extracted DNA. Several limitations were inherent to our study. Although we found MMc in $20 \%$ of the cases, the number of patients included in the study was limited. Furthermore, in agreement with Alizadeh et al. (27), the sensitivity of the RQ-PCR chimerism method is $0.01 \%$ for most markers. Below $0.1 \%$, the linearity of the method is disrupted, but the sensitivity may still be as low as $0.01 \%$. The level of maternal chimerism varies between individuals, and although this method was very sensitive, an even more sensitive method might have yielded more positive cases.

Thus, in theory, this method may underestimate MMc. Moreover, because we did not carry out any in situ analysis, 


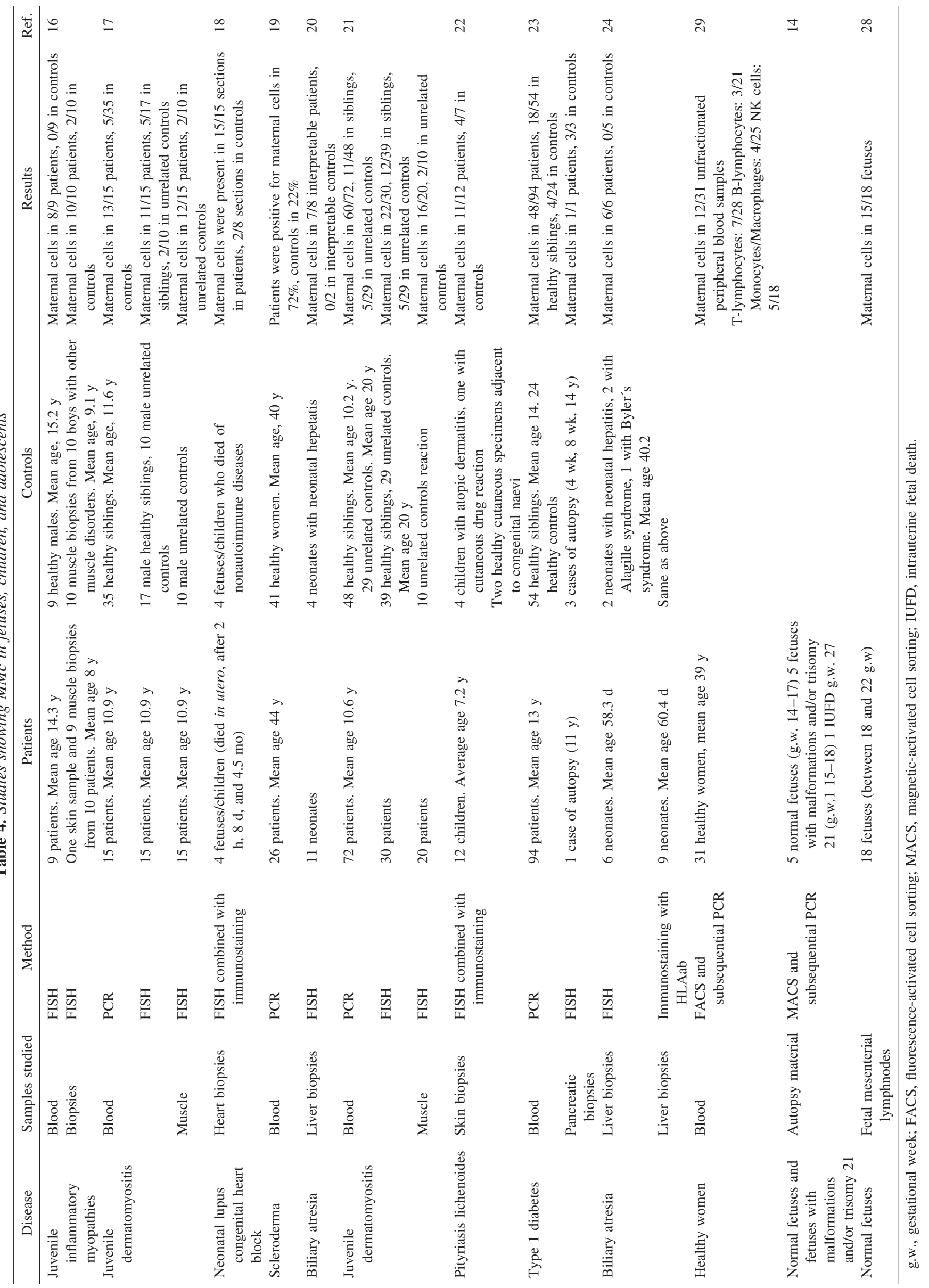


we were unable to evaluate the anatomical location and integration of these cells. We, therefore, cannot claim that the maternal cells are integrated into the tonsil tissue or that these cells are circulating in the small vessels associated with the crypts of the tonsil. This issues require further studies combining immunohistochemistry with other techniques for identification of maternal cells, such as in situ hybridization for $\mathrm{X}$ and Y chromosomes. Similarly, although our data suggests good correlation between blood and tonsillar tissue MMc, the issue is not resolved because we have not provided evidence for engraftment of maternal chimeric cells.

Questions remain as to why MMc persists in some individuals despite HLA disparity between mother and child. The mechanism by which maternal cells are recognized and tolerated by the fetus is unknown, but it is plausible that acceptance of maternal cells is a function of the immature immune system of the unborn child. In this study, we were unable to demonstrate any obvious relationship between HLA types of mother and child and the presence of MMc; however, the relatively limited material in our study did not allow for a definitive answer about whether HLA compatibility between mother and child may influence the appearance (or type) of MMc.

The biologic significance of MMc is not known. MMc appears to be a part of normal biology and some evidences suggest that MMc plays an important role in the mother's progeny. Recently, Mold et al. (29) presented evidence that maternal cells cross the placenta and reside in fetal lymph nodes. Moreover, some of these cells induced the development of fetal cells into CD4+CD25 high Fox p3+Tregs that serve to suppress fetal antimaternal immunity and thereby the reaction to noninherited maternal alleles (NIMAs). In addition, some data suggest that maternal cells and antigen modulate the antigen-specific reactivity of the fetal immune system and thereby induce a long-lasting form of tolerance. In a study of kidney transplantation, Burlingham et al. (36) demonstrated that for a kidney from a sibling donor who is mismatched with the recipient for one HLA haplotype, graft survival is higher when the donor has maternal HLA antigens not inherited by the recipient. Furthermore, the presence of NIMAs in other types of transplantations is associated with fewer rejections than transplants carrying noninherited paternal alloantigens $(37,38)$. Thus, these studies suggest that $\mathrm{T}$ cell tolerance to alloantigens during fetal life may be maintained after birth. Similar findings have been described with regard to B-cell tolerance (39). The prospect of a close interaction between mother and fetus with regard to immunologic function and development may have far-reaching consequences in understanding pregnancy, fetal complications, tolerance to antigens, and transmission of infective agents during pregnancy. In accordance with such speculation, a recent study by Mackelprang et al. (40) demonstrated that the risk for in utero and breast milk HIV-1 transmission is increased with HLA concordance and homozygosity.

Another consideration when speculating about the function of maternal cells is whether these cells are able to demonstrate cellular plasticity. Stevens et al. (19) in studies on MMc in myocardium of children with neonatal lupus syndrome demonstrated evidence that maternal cells had differentiated into cardiac myocytes. In our previous studies, we demonstrated that CD $34+$ and CD $45+$ cells can be transferred across the placenta from the mother to the fetus. Both these cell types might exhibit plasticity properties (41).

Another consideration when speculating about the function of maternal cells is whether these cells are able to demonstrate cellular plasticity. In our previous studies, we demonstrated that CD $34+$ and CD $45+$ cells can be transferred across the placenta from the mother to the fetus. These cells express a cell marker for hematopoietic and endothelial cell progenitors. Stevens et al. (19) studied similar cell markers in heart tissue of children with neonatal lupus and congenital heart block and demonstrated that $86 \%$ of cells of maternal origin found in the myocardium also expressed sarcomeric $\alpha$-actin, a specific marker of cardiomyocytes. Thus, maternal cells in tissues of the offspring appear to be able to exhibit plasticity. This natural plasticity may play an important role in the influence of the mother on her offspring. This mechanism may also explain how acquired abilities, both beneficial and/or detrimental to the child, may be transferred from one generation to another as an epigenetic effect.

In conclusion, MMc was found in $20 \%$ of tonsil and adenoid tissue samples from healthy children from 2 to $15 \mathrm{y}$ of age. To our knowledge, this study is the first to investigate MMc in these tissues. Because these organs have central roles in immune regulation of the developing child, further studies are needed to explore the biologic effects of MMc in these tissues.

\section{REFERENCES}

1. Bianchi DW, Zickwolf GK, Weil GJ, Sylvester S, DeMaria MA 1996 Male feta progenitor cells persist in maternal blood for as long as 27 years postpartum. Proc Natl Acad Sci USA 93:705-708

2. Maloney S, Smith A, Furst DE, Myerson D, Rupert K, Evans PC, Nelson JL 1999 Microchimerism of maternal origin persists into adult life. J Clin Invest 104:41-47

3. Johnson KL, Nelson JL, Furst DE, McSweeney PA, Roberts DJ, Zhen DK, Bianchi DW 2001 Fetal cell microchimerism in tissue from multiple sites in women with systemic sclerosis. Arthritis Rheum 44:1848-1854

4. Lambert NC, Lo YM, Erickson TD, Tylee TS, Guthrie KA, Furst DE 2002 Male microchimerism in healthy women and women with scleroderma: cells or circulating DNA? A quantitative answer. Blood 100:2845-2851

5. Kremer Hovinga IC, Koopmans M, Grootscholten C, van der Wal AM, Bijl M, Derksen RH, Voskuyl AE, de Heer E, Bruijn JA, Berden JH, Bajema IM 2008 Pregnancy, chimerism and lupus nephritis: a multi-centre study. Lupus 17:541-547

6. Johnson KL, McAlindon TE, Mulcahy E, Bianchi DW 2001 Microchimerism in a female patient with systemic lupus erythematosus. Arthritis Rheum 44:2107-2111

7. Johnson KL, Samura O, Nelson JL, McDonnell M, Bianchi DW 2002 Significant fetal cell microchimerism in a nontransfused woman with hepatitis C: evidence of long-term survival and expansion. Hepatology 36:1295-1297

8. Khosrotehrani K, Johnson KL, Cha DH, Salomon RN, Bianchi DW 2004 Transfer of fetal cells with multilineage potential to maternal tissue. JAMA 292:75-80

9. Stevens AM 2006 Microchimeric cells in systemic lupus erythematosus: targets or innocent bystanders? Lupus 15:820-826

10. Lo ES, Lo YM, Hjelm NM, Thilaganathan B 1998 Transfer of nucleated maternal cells into fetal circulation during the second trimester of pregnancy. $\mathrm{Br} \mathrm{J}$ Haematol 100:605-606

11. Socié G, Gluckman E, Carosella E, Brossard Y, Lafon C, Brison O 1994 Search for maternal cells in human umbilical cord blood by polymerase chain reaction amplification of two minisatellite sequences. Blood 83:340-344

12. Hall JM, Lingenfelter P, Adams SL, Lasser D, Hansen JA, Bean MA 1995 Detection of maternal cells in human umbilical cord blood using fluorescence in situ hybridization. Blood 86:2829-2832

13. Petit T, Gluckman E, Carosella E, Brossard Y, Brison O, Socie G 1995 A highly sensitive polymerase chain reaction method reveals the ubiquitous presence of maternal cells in human umbilical cord blood. Exp Hematol 23:1601-1605

14. Jonsson AM, Uzunel M, Götherström C, Papadogiannakis N, Westgren M 2008 Maternal microchimerism in human fetal tissues. Am J Obstet Gynecol 198:325.e1325.e6

15. Stevens AM, Hermes HM, Kiefer MM, Rutledge JC, Nelson JL 2009 Chimeric maternal cells with tissue-specific antigen expression and morphology are common in infant tissues. Pediatr Dev Pathol 12:337-346 
16. Artlett CM, Ramos R, Jiminez SA, Patterson K, Miller FW, Rider LG 2000 Chimeric cells of maternal origin in juvenile idiopathic inflammatory myopathies. Lancet 356:2155-2156

17. Reed AM, Picornell YJ, Harwood A, Kredich DW 2000 Chimerism in children with juvenile dermatomyositis. Lancet 356:2156-2157

18. Stevens AM, Hermes HM, Rutledge JC, Buyon JP, Nelson JL 2003 Myocardialtissue-specific phenotype of maternal microchimerism in neonatal lupus congenital heart block. Lancet 362:1617-1623

19. Lambert NC, Erickson TD, Yan Z, Pang JM, Guthrie KA, Furst DE, Nelson JL 2004 Quantification of maternal microchimerism by HLA-specific real-time polymerase chain reaction: studies of healthy women and women with scleroderma. Arthritis Rheum 50:906-914

20. Suskind DL, Rosenthal P, Heyman MB, Kong D, Magrane G, Baxter-Lowe LA, Muench MO 2004 Maternal microchimerism in the livers of patients with biliary atresia. BMC Gastroenterol 4:14

21. Reed AM, McNallan K, Wettstein P, Vehe R, Ober C 2004 Does HLA-dependent chimerism underlie the pathogenesis of juvenile dermatomyositis? J Immunol 172:5041-5046

22. Khosrotehrani K, Guegan S, Fraitag S, Oster M, de Prost Y, Bodemer C, Aractingi S 2006 Presence of chimeric maternally derived keratinocytes in cutaneous inflammatory diseases of children: the example of pityriasis lichenoides. J Invest Dermatol 126:345-348

23. Nelson JL, Gillespie KM, Lambert NC, Stevens AM, Loubiere LS, Rutledge JC, Leisenring WM, Erickson TD, Yan Z, Mullarkey ME, Boespflug ND, Bingley PJ, Gale EA 2007 Maternal microchimerism in peripheral blood in type 1 diabetes and pancreatic islet beta cell microchimerism. Proc Natl Acad Sci USA 104:1637-1642

24. Kobayashi H, Tamatani T, Tamura T, Kusafuka J, Yamataka A, Lane GJ, Kawasaki S, Ishizaki Y, Mizuta K, Kawarasaki H, Gittes GK 2007 Maternal microchimerism in biliary atresia. J Pediatr Surg 42:987-991

25. Strauchen JA, Miller LK 2003 Lymphoid progenitor cells in human tonsils. Int J Surg Pathol 11:21-24

26. Alizadeh M, Bernard M, Danic B, Dauriac C, Birebent B, Lapart C, Lamy T, Le Prisé PY, Beauplet A, Bories D, Semana G, Quelvennec E 2002 Quantitative assessment of hematopoietic chimerism after bone marrow transplantation by realtime quantitative polymerase chain reaction. Blood 99:4618-4625

27. Willasch A, Schneider G, Reincke BS, Shayegi N, Kreyenberg H, Kuci S, Weber G, Van Der Reijden B, Niethammer D, Klingebiel T, Bader P 2007 Sequence polymorphism systems for quantitative real-time polymerase chain reaction to characterize hematopoietic chimerism-high informativity and sensitivity as well as excellent reproducibility and precision of measurement. Lab Hematol 13:73-84
28. Mold JE, Michaëlsson J, Burt TD, Muench MO, Beckerman KP, Busch MP, Lee TH, Nixon DF, McCune JM 2008 Maternal alloantigens promote the development of tolerogenic fetal regulatory $\mathrm{T}$ cells in utero. Science 322:1562-1565

29. Loubière LS, Lambert NC, Flinn LJ, Erickson TD, Yan Z, Guthrie KA, Vickers KT, Nelson JL 2006 Maternal microchimerism in healthy adults in lymphocytes, monocyte/macrophages and NK cells. Lab Invest 86:1185-1192

30. Srivatsa B, Srivatsa S, Johnson KL, Bianchi DW 2003 Maternal cell microchimerism in newborn tissues. J Pediatr 142:31-35

31. Tang X, Hori S, Osamura RY, Tsutsumi Y 1995 Reticular crypt epithelium and intra-epithelial lymphoid cells in the hyperplastic human palatine tonsil: an immunohistochemical analysis. Pathol Int 45:34-44

32. Brandtzaeg P, Surjan L Jr, Berdal P 1979 Immunoglobulin-producing cells in clinically normal, hyperplastic and inflamed human palatine tonsils. Acta Otolaryngol Suppl 360:211-215

33. Ivarsson M, Lundberg C, Quiding-Jarbrink M 2004 Antibody production directed against pneumococci by immunocytes in the adenoid surface secretion. Int J Pediatr Otorhinolaryngol 68:537-543

34. Ivarsson M, Lundin BS, Lundberg C 2002 Activated T cells in the surface secretion on the adenoid-a flow cytometric study. Scand J Immunol 56:310-314

35. Burlingham WJ, Grailer AP, Heisey DM, Claas FH, Norman D, Mohanakumar T, Brennan DC, de Fijter H, van Gelder T, Pirsch JD, Sollinger HW, Bean MA 1998 The effect of tolerance to noninherited maternal HLA antigens on the survival of renal transplants from sibling donors. N Engl J Med 339:1657-1664

36. Peer LA, Bernhard W, Walker JC Jr 1958 Full-thickness skin exchanges between parents and their children. Am J Surg 95:239-245

37. van Rood JJ, Loberiza FR Jr, Zhang MJ, Oudshoorn M, Claas F, Cairo MS 2002 Effect of tolerance to noninherited maternal antigens on the occurrence of graftversus-host disease after bone marrow transplantation from a parent or an HLAhaploidentical sibling. Blood 99:1572-1577

38. Claas FH, Gijbels Y, van der Velden-de Munck J, van Rood JJ 1988 Induction of B cell unresponsiveness to noninherited maternal HLA antigens during fetal life. Science 241:1815-1817

39. Mackelprang RD, John-Stewart G, Carrington M, Richardson B, Rowland-Jones S, Gao X, Mbori-Ngacha D, Mabuka J, Lohman-Payne B, Farquhar C 2008 Maternal HLA homozygosity and mother-child HLA concordance increase the risk of vertical transmission of HIV-1. J Infect Dis 197:1156-1161

40. Vieyra DS, Jackson KA, Goodell MA 2005 Plasticity and tissue regenerative potential of bone marrow-derived cells. Stem Cell Rev 1:65-69 